\title{
THE INVESTIGATION OF SPECTROSCOPIC AND THEORETICAL METHODS OF BISISOXAOLINE DERIVATIVE OF NORBORNADIEN
}

\author{
Kerem MESCI ${ }^{1}$, Serpil ERYILMAZ ${ }^{2}$, Melek GÜL ${ }^{3}$, Ersin İNKAYA ${ }^{4}$ \\ ${ }^{1}$ Department of Physics, Institute of Science, Amasya University, Amasya, TURKEY \\ ${ }^{2}$ Department of Physics, Faculty of Arts and Sciences, Amasya University, Amasya, TURKEY \\ ${ }^{3}$ Department of Chemistry, Faculty of Arts and Sciences, Amasya University, Amasya, TURKEY \\ ${ }^{4}$ Central Research Laboratory, Amasya University, Amasya, TURKEY
}

\begin{abstract}
In this study, the synthesis of bisisoxaoline derivative of norbornadien from heterocyclic compounds was performed via 1,3dipolar cycloaddition reaction, the structural properties of derivative characterized by spectroscopic analysis such as FT-IR, ${ }^{1} \mathrm{H}-\mathrm{NMR},{ }^{13} \mathrm{C}-\mathrm{NMR}$, UV-Vis and the single-crystal X-ray diffraction technique. The 3,7-bis(4-(tert-butyl)phenyl)3a,4,4a,7a,8,8a-hexahydro-4,8-methanobenzo[1,2-d:4,5-d']diisoxazole compound was optimized using Density Functional Theory (DFT/B3LYP) method with 6-311G(d,p) basis set in the ground state and the geometric parameters compared with single-crystal X-ray diffraction technique. The compound crystallizes in the monoclinic space group $C 2 / c$ with $a=20.634(4)$ $\AA, b=11.179(2) \AA, c=11.0690(17) \AA$ and $Z=4$ unit cell parameters. Also, the spectral results were examined with calculated vibrational frequencies, ${ }^{1} \mathrm{H}-\mathrm{NMR},{ }^{13} \mathrm{C}-\mathrm{NMR}$ chemical shift values and absorption wavelengths, theoretically. The energetic behaviour of the compound in different solvent media was examined with TD-DFT/B3LYP method and 6-311G(d,p) basis set using the Conductor Polarizable Continuum Model (CPCM). The frontier molecular orbitals (FMOs), molecular electrostatic potential (MEP) and electronic structure parameters (dipole moment, electronegativity, chemical hardness-softness, ionization potential, electron affinity, etc.) were examined to get information about the chemical stability of the structure.
\end{abstract}

Keywords: Bisisoxaoline, DFT, Single Crystal X-ray, FT-IR, NMR

\section{INTRODUCTION}

1,3-dipolar cycloaddition is not only powerful tool for the synthesis of five membered heterocyclic compounds, but also generated new chiral centres [1]. In recent years, the isoxazoline compounds were obtained from nitrile oxides via 1,3-dipolar cycloaddition reaction since they are significant role in organic and pharmacologically active compounds. The moiety of isoxazoline has been found in various biological activities. Bicyclic isoxazoline derivative which is GABA analogues (1), is known to exhibit anticonvulsant activity [3]. The Lee 878 (2) compound is effective of antimicrobial against of Mycobacterium tuberculosis [4]. The biologically active isoxazoline derivatives are shown in Figure 1. Lee and co-workers have been found antituberculosis activity of organic compounds as a core unit of isoxazoline groups [5].<smiles>O=[N+]([O-])c1ccc(C2=NOC(c3ccc(N4CCN(Cc5ccccc5)CC4)cc3)C2)o1</smiles>

Figure 1. Biologically active Isoxazoline derivatives

*Corresponding Author: srpleryilmaz@gmail.com 
Nitrile oxide compounds were obtained from aldoxime via one-pot reaction. Aromatic aldehyde was converted aldoxime compounds before were treated $\mathrm{NaOCl}$ to obtained hydroximoyl chloride followed dehydrohalogenation [6].

In literature, some isoxazoline compounds of 2,5-norbornadiene derivatives are include as mono-dipolar cycloaddition reaction [7]. We haven't found any data about one-pout domino cycloaddition reaction of 2,5-norbornadiene with nitrile oxides.

So, we examined structural properties of the 3,7-bis(4-(tert-butyl)phenyl)-3a,4,4a,7a,8,8a-hexahydro4,8-methanobenzo[1,2-d:4,5-d'] diisoxazole compound with spectroscopic and theoretical methods. The chemical structure of the synthesized compound was characterized with FT-IR, ${ }^{1} \mathrm{H}-\mathrm{NMR},{ }^{13} \mathrm{C}-\mathrm{NMR}$, $\mathrm{UV}$-Vis and the single-crystal X-ray diffraction technique.

The theoretical molecular geometry parameters, vibrational frequencies, chemical shift and absorbance wavelength values were compared with the experimental results. The energetic behaviour of the compound in different solvent media was examined. In addition, physical and chemical properties of the compound were investigated by frontier molecular orbital energies and dipole moment, electronegativity, chemical hardness-softness etc. electronic structure parameters.

\section{MATERIAL AND METHODS}

\subsection{Synthesis Process}

In this study, we synthesized an isoxazoline derivatives of according to the structure of 2,5norbornadiene, which is include symmetrically two double bond, for use domino cycloaddition reaction. We have recently reported reaction condition of nitrile oxide addition via dipolar cycloaddition reaction [8]. Under the reaction conditions, the nitrile oxides cycloaddition reaction was investigated for the domino cycloaddition. The reaction condition is shown in Figure 2. Further shorten the reaction time to 3 hours; yield was observed increasing under ultrasound system as green chemical method. When the reaction performed with a 4-tert-butylbenzaldoxime $(3.3 \mathrm{mmol})$ and 2,5 -norbornadiene $(1 \mathrm{mmol})$, the reaction provided the domino cycloaddition product $(3)$ in $85 \%$ yield. We determined that treatment of the 4-tert-butylbenzaldehyde with hydroxylamine hydrochloride which gave aldoxime compounds. The purification of aldoxime compounds via column chromatography and the crystallization with chloroform.

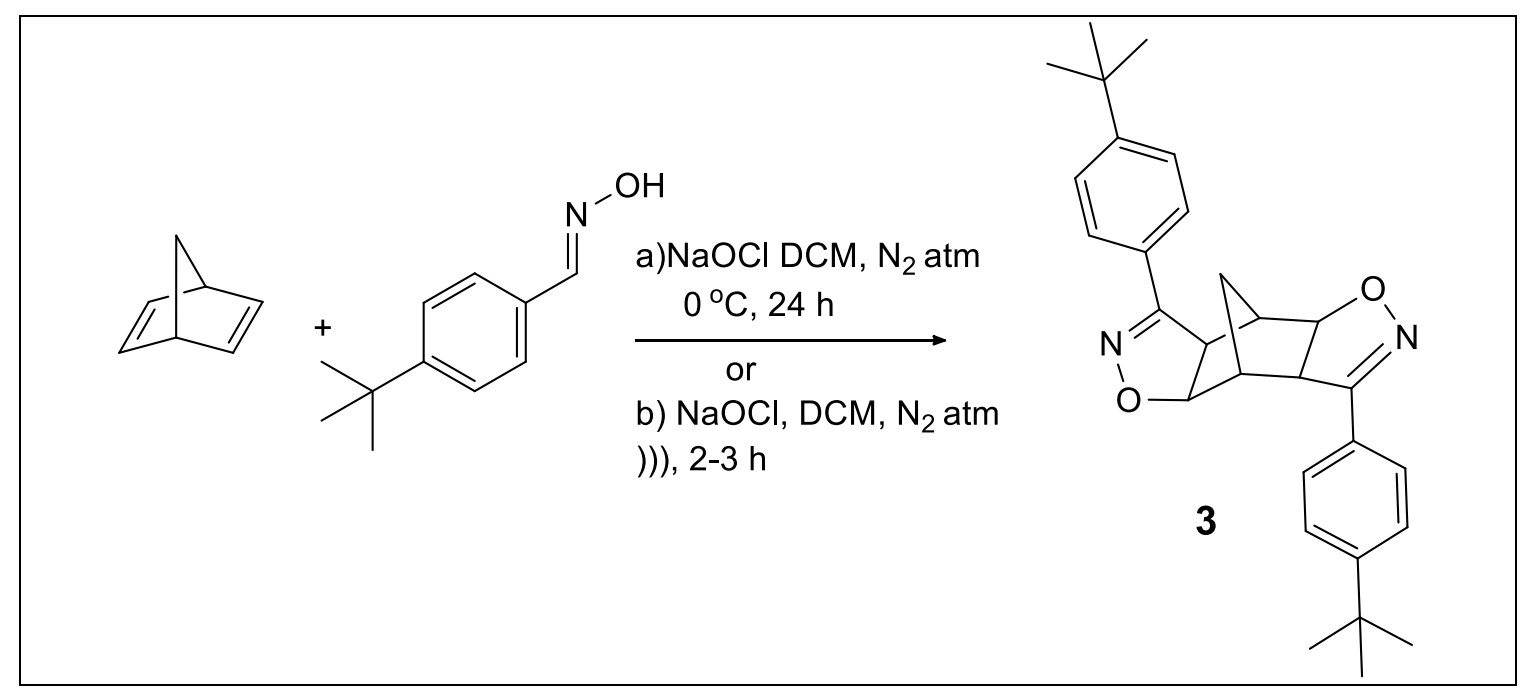

Figure 2. Domino cycloaddition reaction condition. 
A three-neck round bottomed flask was charged with the appropriate 2,5-norbornadiene (1 equiv), aldoxime (3.3 equiv), and anhydrous DCM $(5 \mathrm{~mL}$ was the mixture sonicated with started drop wise $\mathrm{NaOCl}$ (2.5 equiv) added via syringe, under $\mathrm{N}_{2}$ for 0.5 hours until TLC (1:2, EtOAc: hexanes) dedicated completion of aldoxime. The reaction mixture was extracted three times with diethyl ether and brine. The residue was purified directly by column chromatography to give the desired isoxazoline.

\section{Compound (3):}

3,7-bis(4-(tert-butyl)phenyl)-3a,4,4a,7a,8,8a-hexahydro-4,8-methanobenzo[1,2-d:4,5-d']diisoxazole. Colourless crystals, $85 \%$ yield, m.p. $128^{\circ} \mathrm{C}, R \mathrm{f}=0.41(1: 2$, ethyl acetate/n-hexane).

FT-IR [KBr/ $\left.\left(\mathbf{c m}^{-1}\right)\right]: 2956.20,2927,2865.3,1609.11,1591.7,1514.5,1409.57,1394.9,1361.12$, 1248.2, 1112.95, 904.72,888.11, 835.93.

${ }^{1} \mathbf{H}-N M R\left(400 ~ M H z, \mathbf{C D C l}_{3}\right) \boldsymbol{\delta}: \delta 7.64\left(\mathrm{~m}, 4 \mathrm{H} \mathrm{H} 7, \mathrm{H} 9, \mathrm{H}^{\mathrm{i}}\right.$ ve H9i), $7.45(\mathrm{~d}, J=8.4 \mathrm{~Hz}, 4 \mathrm{H}, \mathrm{H} 6, \mathrm{H} 10$, $\mathrm{H}^{\mathrm{i}}$ ve $\left.\mathrm{H} 10^{\mathrm{i}}\right), 4.84(\mathrm{~d}, J=8.2 \mathrm{~Hz}, 1 \mathrm{H}, \mathrm{H} 12), 4.75\left(\mathrm{~d}, J=8.3 \mathrm{~Hz}, 1 \mathrm{H}, \mathrm{H} 12^{\mathrm{i}}\right), 3.83(\mathrm{~d}, J=8.3 \mathrm{~Hz}, 1 \mathrm{H}$, H13), 3.65 (d, $J=8.2 \mathrm{~Hz}, 1 \mathrm{H}, \mathrm{H} 13^{\mathrm{i}}$ ), 2.95 (brs, 2H, H14, H14 $4^{\mathrm{i}}, 1.59$ (d, $\left.J=6.2 \mathrm{~Hz}, 2 \mathrm{H}, \mathrm{H} 15 \mathrm{a}, \mathrm{b}\right), 1.34$ (s, 18H, tert-butyl) ppm.

${ }^{13}$ C-NMR (100 MHz, $\left.\mathbf{C D C l}_{3}\right)$ d: $155.62,155.50,153.72,153.61,126.64,126.49,125.87,125.79$, $125.54,86.36,83.27,56.77,52.85,50.78,46.06,34.89,31.16,26.96 \mathrm{ppm}$.

LC-MS: $\mathrm{C}_{29} \mathrm{H}_{34} \mathrm{~N}_{2} \mathrm{O}_{2}(\mathrm{~m} / \mathrm{z}) 442.26$.

\subsection{Experimental Details and Spectroscopic Analysis Instruments}

All the reaction materials used were commercially available and use drying DCM over $\mathrm{CaH}_{2}$. Ultrasound assisted reactions were carried out using a Bandelin ultrasound with $35 \mathrm{kHz}$ frequency. IR spectra was obtained with a "Perkin Elmer, FT-IR" system and reported in terms of frequency of absorption $\left(\mathrm{cm}^{-1}\right)$. Melting point was determined on a capillary point apparatus equipped with digital thermometer, "Thermo". NMR spectra were determined with a "Bruker Ac-400 MHz NMR". TMS (tetramethylsilane) was used as an internal standard and $\mathrm{CDCl}_{3}$ was used as the solvent. Signal multiplicities in the NMR spectra were reported as follows: s-singlet, brs-broad singlet, d-doublet, dd-doublet of doublets, mmultiplet. Elemental analysis was determined by Leco-Truspec CHNS Elemental analyzer. Mass spectrometer was measured with AB-Sciex LC-MS/MS-QTrap. The compound has been identified in the AUMAULAB Central Laboratory in Amasya University in Turkey.

\subsection{X-ray Crystallography}

The single-crystal X-ray data was collected on a Bruker D8 QUEST diffractometer. All diffraction measurements were performed at room temperature $(296 \mathrm{~K})$ using graphite monochromated Mo-Ka radiation $(\lambda=0.71073 \AA)$. Reflection data was recorded in the rotation mode using the $\omega$ scan technique by using X-AREA software [9]. Unit cell parameters were determined from least-squares refinement of setting angels with $\theta$ in the range $3.5 \leq \theta \leq 22.4$. The structure was solved by direct methods using SHELXS-97 [10] implemented in WinGX [11] program suit. The refinement was carried out by fullmatrix least-squares method on the positional and anisotropic temperature parameters of the nonhydrogen atoms or equivalently corresponding to 191 crystallographic parameters, using SHELXL-97 [12]. Data collection: X-AREA, cell refinement: X-AREA, data reduction: X-RED32 [13]. The general purpose crystallographic tool PLATON [14] was used for the structure analysis and presentation of the results. The molecular graphic were done using ORTEP-3 for Windows [11]. Details of the data collection conditions and the parameters of the refinement process are given in Table 1. 
Table 1. Crystal data and structure refinement parameters for the (3) compound

\begin{tabular}{|c|c|}
\hline CCDC deposition no. & 1444550 \\
\hline Colour & Colourless \\
\hline Chemical formula & $\mathrm{C}_{29} \mathrm{H}_{34} \mathrm{~N}_{2} \mathrm{O}_{2}$ \\
\hline Formula weight & 442.58 \\
\hline Temperature (K) & 296 \\
\hline Wavelength $(\AA)$ & $0.71073 \mathrm{Mo}-\mathrm{K} \alpha$ \\
\hline Crystal system & Monoclinic \\
\hline Space group & $C 2 / c$ \\
\hline \multicolumn{2}{|l|}{ Unit cell parameters } \\
\hline$a, b, c(\AA)$ & $20.634(4), 11.179(2), 11.0690(17)$ \\
\hline B & $101.012(5)$ \\
\hline Volume $\left(\AA^{3}\right)$ & $2506.2(8)$ \\
\hline$Z$ & 4 \\
\hline$D_{\text {calc }}\left(\mathrm{g} / \mathrm{cm}^{3}\right)$ & 1.173 \\
\hline$\mu\left(\mathrm{mm}^{-1}\right)$ & 0.07 \\
\hline$F(000)$ & 952 \\
\hline Crystal size $\left(\mathrm{mm}^{3}\right)$ & $0.13 \times 0.09 \times 0.08$ \\
\hline Diffractometer/measurement method & Bruker D8 QUEST 2/ $\omega$ scan \\
\hline Index ranges & $-25 \leq h \leq 25,-13 \leq k \leq 13,-9 \leq l \leq 13$ \\
\hline$\theta$ range for data collection $\left(^{\circ}\right)$ & $3.5 \leq \theta \leq 22.4$ \\
\hline Reflections collected & 14380 \\
\hline Independent/observed reflections & $2468 / 1104$ \\
\hline$R_{\text {int }}$ & 0.123 \\
\hline Refinement method & Full-matrix least-squares on $F^{2}$ \\
\hline Data/restraints/parameters & $14380 / 0 / 150$ \\
\hline Goodness-of-fit on $F^{2}$ & 1.02 \\
\hline$\Delta \rho_{\max }, \Delta \rho_{\min }\left(\mathrm{e} / \AA^{3}\right)$ & $0.24,-0.24$ \\
\hline
\end{tabular}

\subsection{Theoretical Calculations Process}

All the theoretical analysis on the structure have been performed with Gaussian 09W [15] electronic structure and GaussView 5.0 [16] graphical interface programmes. Primarily, the initial molecular geometry of the compound (3) was taken on the coordinates obtained from the X-ray diffraction data and the optimization process was carried out DFT / B3LYP (Becke's Three Parameter Hybrid Functional using the Lee, Yang and Parr Correlation Functional) [17-19] method with 6-311G(d,p) the basis set in the ground state. And all theoretical calculations were made over the optimized structure and the same method. To examine the IR spectral character of the compound (3), harmonic vibrational frequencies were calculated and to eliminate systematic errors between the experimental values and theoretical 
values the frequencies multiplied by the scale 0.9682 [20]. ${ }^{1} \mathrm{H}$ and ${ }^{13} \mathrm{C}-\mathrm{NMR}$ chemical shift values were calculated according to GIAO (Gauge-Independent Atomic Orbital) method [21], and also TMS (tetramethylsilane) which an internal standard chemical shifts, as solvent $\mathrm{CDCI}_{3}$. To examine the impact of the solvent effect on electronic transitions in the UV-VIS spectral analysis, theoretical transition wavelengths are calculated at different solvent media such as dimethyl sulfoxide, tetrahydrofuran and methanol with Time Dependent TD/DFT using Conductor Polarizable Continuum Model (CPCM) [22] at the basis set $6-311 \mathrm{G}(\mathrm{d}, \mathrm{p})$. The frontier molecular orbital energies-the highest energy occupied molecular orbital (HOMO) and the lowest unoccupied molecular orbital energy (LUMO)-have been calculated and provided very useful information in determining the energy and electronic transitions. Furthermore, molecular electrostatic potential (MEP) map and some structure parameters (the dipole moment, electronegativity, chemical hardness-softness, ionization potential, electron affinity, etc.) were examined using the same theoretical method in order to gain information about chemical reactivity of the compound (3).

\section{RESULTS AND DISCUSSION}

\subsection{Description of the Single-Crystal Structure and Optimized Structure}

The molecular structure of 3,7-bis(4-(tert-butyl)phenyl)-3a,4,4a,7a,8,8a-hexahydro-4,8methanobenzo[1,2-d:4,5-d']diisoxazole with the atom numbering scheme is shown in Figure 3.a. The (3) molecule is monoclinic having space group $C 2 / c$, with four molecules in unit cell $(\mathrm{Z}=4)$, with following dimensions $\mathrm{a}=20.634(4) \AA, \mathrm{b}=11.179(2) \AA, \mathrm{c}=11,0690(17) \AA$ and $\beta=101.012(5)^{\circ}$. The molecule resides on mirror symmetry located on the $\mathrm{C} 15$ atom.

The molecule is consists of four groups. One of them, which is important for our works, is isoxazole ring. The other groups are, bicyclic ring, phenyl ring and tert-butyl group. The isoxazole ring is planar with a maximum deviation of 0.0023 (11) $\AA$ for atom $\mathrm{C} 11$. All bond lengths $(\mathrm{C}-\mathrm{C} 1.496-1.539 \AA, \mathrm{C}=\mathrm{N}$ $1.281 \AA, \mathrm{C}-\mathrm{O} 1.454 \AA$, and $\mathrm{O}-\mathrm{N} 1.414 \AA$ ) on the isoxazole ring are in the acceptable range and similar with literature value $[8,23]$. The $\mathrm{C}=\mathrm{N}$ bond length of $1.281 \AA$ confirms it's a double bond. The tertbutyl group $\mathrm{C}-\mathrm{C}$ bond lengths $\mathrm{C} 1-\mathrm{C} 4, \mathrm{C} 2-\mathrm{C} 4$ and $\mathrm{C} 3-\mathrm{C} 4$ are 1.534(6), 1.509(6) and 1.527(6), respectively. These lengths are similar with literature values [24]. The $\mathrm{C}-\mathrm{C}$ bond lengths in the phenyl rings are observed in the range of 1.368(4) $-1.389(3) \AA$. The bond lengths are consistent with previously phenyl ring-containing studies [25].

In the investigated molecule, there are no remarkable intra-intermolecular hydrogen bond interactions. The molecule stabilized by weak Van der Waals forces.

The optimized structure of the (3) compound, as shown in Figure 3.b. was obtained over the geometry formed by crystallographic data, some selected geometric parameters (such as bond lengths and angles, torsion angles) were compared with experimental values and the results were tabulated in Table 2. 


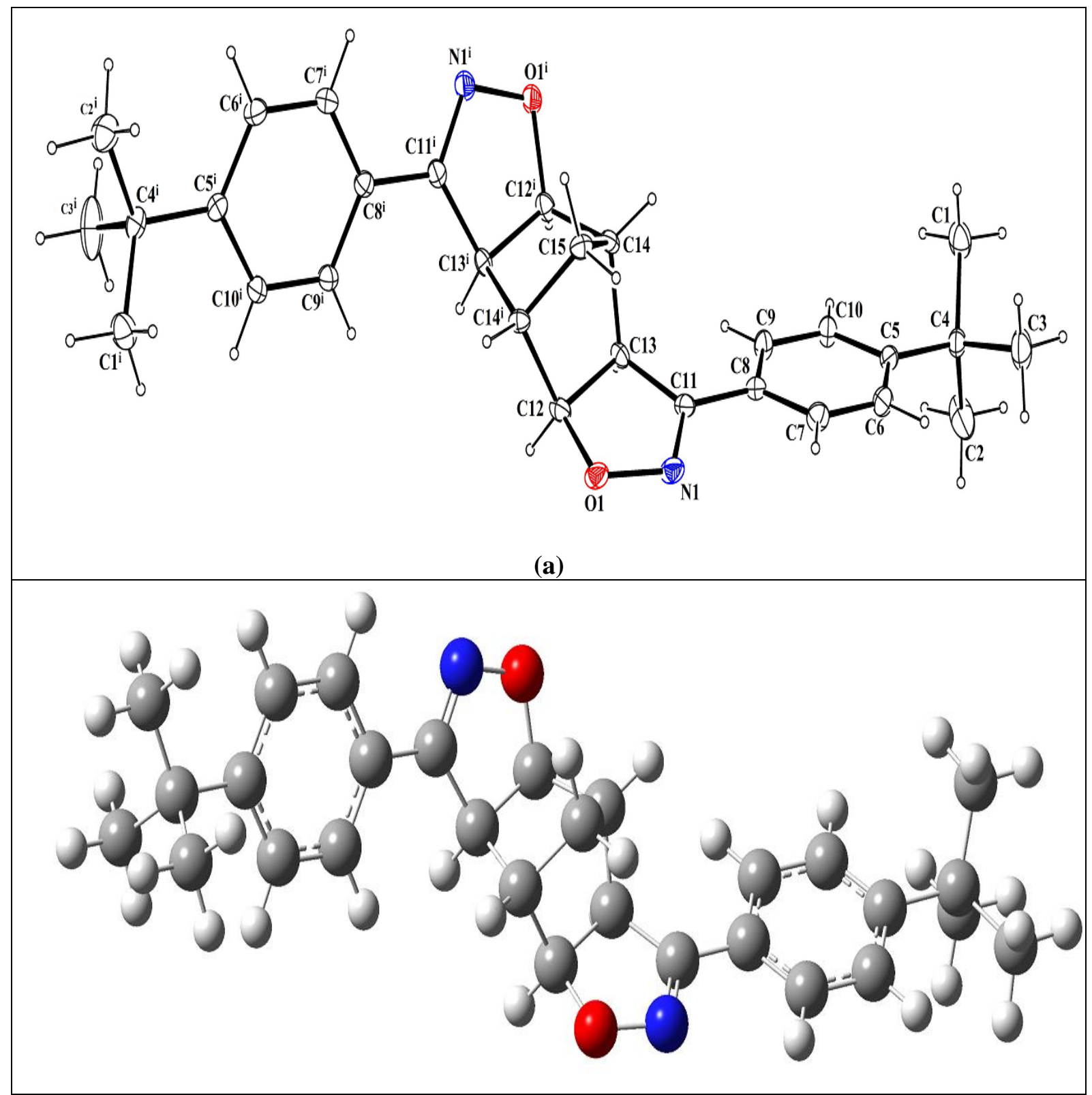

(b)

Figure 3. a) An ORTEP-3 view of the (3) compound showing the atom-numbering scheme. Displacement ellipsoids are drawn at the $20 \%$ probability level and $\mathrm{H}$ atoms are shown as small spheres of arbitrary radii. b) The optimized geometric structure of the (3) compound with DFT/B3LYP method and 6-311G(d,p) basis set.

As can be seen from the Table 2, N1-C11, N1-O1, O1-C12 bond lengths are 1.281(4), 1.414(4), 1.454(4) $\AA$ experimentally, $1.284,1.393,1.451 \AA$ theoretically. These values were indicated as $1.290,1.383$, $1.478 \AA$ for $6-31 \mathrm{G}(\mathrm{d}, \mathrm{p})$ basis set, $1.285,1.380,1.480 \AA$ for $6-311+\mathrm{G}(\mathrm{d}, \mathrm{p})$ basis set [26], 1.285, 1.388, $1.453 \AA$ for 6-311G(d,p) basis set [8], in other DFT studies on the isoxazole derivatives which performed by our group. Also C12-C13 and C11-C13 bond lengths are stated as 1.553, $1.514 \AA$, theoretically, and we can say that $\mathrm{C}=\mathrm{N}, \mathrm{N}-\mathrm{O}, \mathrm{C}-\mathrm{O}, \mathrm{C}-\mathrm{C}$ bond lengths within the isoxazole ring are in agreement with both reported in similar paper and typical values $(\mathrm{C}=\mathrm{N} 1.47 \AA$, N-O $1.40 \AA \mathrm{C}-\mathrm{O} 1.43 \AA$, C-C $1.54 \AA$ ). C12$\mathrm{C} 13$ bond length which connecting between isoxazole and bicyclic groups is the longest length and recorded as 1.539(4) Å experimental, $1.553 \AA$ theoretical. 
$\mathrm{C} 12^{\mathrm{i}}-\mathrm{C} 13^{\mathrm{i}}$ bond length is shown similar result $\mathrm{C} 12-\mathrm{C} 13$ as $1.553 \AA$, and $\mathrm{C} 12-\mathrm{C} 14^{\mathrm{i}}$ is related $\mathrm{C} 12^{\mathrm{i}}-\mathrm{C} 14$ as $1.538 \AA$. These results are referred a mirror symmetry of the (3) compound.

\begin{tabular}{|c|c|c|}
\hline Parameters & $\begin{array}{c}\text { Experimental Values } \\
\text { (X-Ray Analysis) }\end{array}$ & $\begin{array}{c}\text { Theoretical Values } \\
\text { DFT/6-311G }(d, p)\end{array}$ \\
\hline \multicolumn{3}{|c|}{ Bond Lengths (Å) } \\
\hline N1-C11 & $1.281(4)$ & 1.284 \\
\hline N1-O1 & $1.414(4)$ & 1.393 \\
\hline $\mathrm{O} 1-\mathrm{C} 12$ & $1.454(4)$ & 1.451 \\
\hline $\mathrm{C} 12-\mathrm{C} 13$ & $1.539(4)$ & 1.553 \\
\hline $\mathrm{C} 11-\mathrm{C} 13$ & $1.496(5)$ & 1.514 \\
\hline C8-C11 & $1.463(5)$ & 1.469 \\
\hline C4-C5 & $1.518(5)$ & 1.538 \\
\hline $\mathrm{C} 13-\mathrm{C} 14$ & $1.538(5)$ & 1.558 \\
\hline C14-C15 & $1.529(5)$ & 1.541 \\
\hline $\mathrm{C} 15-\mathrm{C} 14^{\mathrm{i}}$ & $1.529(5)$ & 1.541 \\
\hline $\mathrm{C} 12-\mathrm{C} 14^{\mathrm{i}}$ & $1.519(5)$ & 1.538 \\
\hline $\mathrm{C} 14-\mathrm{C} 12^{\mathrm{i}}$ & $1.519(5)$ & 1.538 \\
\hline $\mathrm{C} 1-\mathrm{H} 1 \mathrm{~A} / \mathrm{H} 1 \mathrm{~B} / \mathrm{H} 1 \mathrm{C}$ & & $1.093 / 1.092 / 1.094$ \\
\hline $\mathrm{C} 2-\mathrm{H} 2 \mathrm{~A} / \mathrm{H} 2 \mathrm{~B} / \mathrm{H} 2 \mathrm{C}$ & 0.9600 & $1.092 / 1.094 / 1.093$ \\
\hline $\mathrm{C} 3-\mathrm{H} 3 \mathrm{~A} / \mathrm{H} 3 \mathrm{~B} / \mathrm{H} 3 \mathrm{C}$ & & 1.093 \\
\hline \multicolumn{3}{|c|}{ Bond Angles ( 9} \\
\hline C11-N1-O1 & $110.3(2)$ & 110.8 \\
\hline $\mathrm{N} 1-\mathrm{O} 1-\mathrm{C} 12$ & $109.5(2)$ & 110.1 \\
\hline N1-C11-C8 & $122.2(4)$ & 121.2 \\
\hline $\mathrm{N} 1-\mathrm{C} 11-\mathrm{C} 13$ & $113.6(6)$ & 113.4 \\
\hline $\mathrm{O} 1-\mathrm{C} 12-\mathrm{C} 13$ & $104.7(3)$ & 104.9 \\
\hline C15-C14-C13 & $102.3(2)$ & 102.1 \\
\hline C9-C8-C11 & $120.3(4)$ & 121.1 \\
\hline C15-C14-H14 & 115.0 & 117.0 \\
\hline H15A-C15-H15B & 110.3 & 108.9 \\
\hline $\mathrm{O} 1-\mathrm{C} 12-\mathrm{C} 14^{\mathrm{i}}$ & $111.0(3)$ & 111.5 \\
\hline $\mathrm{C} 12^{\mathrm{i}}-\mathrm{C} 14-\mathrm{C} 13$ & 106.5(3) & 105.6 \\
\hline $\mathrm{C} 14-\mathrm{C} 15-\mathrm{C} 14^{\mathrm{i}}$ & $94.5(4)$ & 94.9 \\
\hline $\mathrm{C} 14^{\mathrm{i}}-\mathrm{C} 12-\mathrm{C} 13$ & 103.9 & 103.9 \\
\hline \multicolumn{3}{|c|}{ Torsion Angles ( 9} \\
\hline C11-N1-O1-C12 & $3.4(4)$ & 2.7 \\
\hline O1-N1-C11-C8 & $-177.3(3)$ & -179.0 \\
\hline O1-N1-C11-C13 & $0.6(4)$ & 0.5 \\
\hline N1-O1-C12-C13 & $-5.7(3)$ & -4.6 \\
\hline $\mathrm{N} 1-\mathrm{C} 11-\mathrm{C} 13-\mathrm{C} 14$ & 106.1(3) & 106.5 \\
\hline $\mathrm{N} 1-\mathrm{C} 11-\mathrm{C} 13-\mathrm{C} 12$ & $-4.0(4)$ & -3.2 \\
\hline O1-C12-C13-C11 & $5.6(3)$ & 4.5 \\
\hline $\mathrm{O} 1-\mathrm{C} 12-\mathrm{C} 13-\mathrm{C} 14$ & $-113.7(3)$ & -115.0 \\
\hline N1-O1-C12-C14 & $-177.2(3)$ & -116.5 \\
\hline 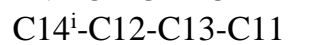 & 122.1(3) & 121.7 \\
\hline $\mathrm{C} 11-\mathrm{C} 13-\mathrm{C} 14-\mathrm{C} 12^{\mathrm{i}}$ & $177.2(3)$ & 178.4 \\
\hline $\mathrm{C} 12^{\mathrm{i}}-\mathrm{C} 14-\mathrm{C} 15-\mathrm{C} 14^{\mathrm{i}}$ & $55.78(19)$ & 55.19 \\
\hline
\end{tabular}

The $\mathrm{C} 12^{\mathrm{i}}-\mathrm{C} 14-\mathrm{C} 13$ and $\mathrm{C} 14-\mathrm{C} 15-\mathrm{C} 14^{\mathrm{i}}$ bond angles of bicyclic ring, which has $\mathrm{sp}^{3}$ hybridized one carbon bridge, are observed as 106.5(3), 94.5(4) ${ }^{\circ}$ experimental, while these angles are 105.6, $94.9^{\circ}$ according to DFT/B3LYP/6-311G(d,p) method. The bond angle between on bridge atoms is stated $93.8^{\circ}$ in other study [8]. In view that, mirror symmetry is not only bond length also bond angles, for example C12$\mathrm{C} 14^{\mathrm{i}}-\mathrm{C} 13^{\mathrm{i}}$ and $\mathrm{C} 12^{\mathrm{i}}-\mathrm{C} 14-\mathrm{C} 13$ as $105.6^{\circ}$.

We should mention that are minor differences between the experimental and theoretical parameters, because compound is accepted in the gas phase during theoretical calculation process, whereas it is solid 
phase in the experimental analysis, and molecules connected to each other with hydrogen bonds in this phase. Figure 4 is shown a global comparison was performed the atom-by-atom superimposition obtained from X-ray diffraction and the theoretical calculations and RMSE value is $0.903 \AA$. Also, we examined correlation coefficients to determine relationships or compliance between experimental and theoretical values. $R^{2}$ value is 0.9679 for bond lengths, 0.9850 for bond angles, and correlation graphics are shown in Figure 5.

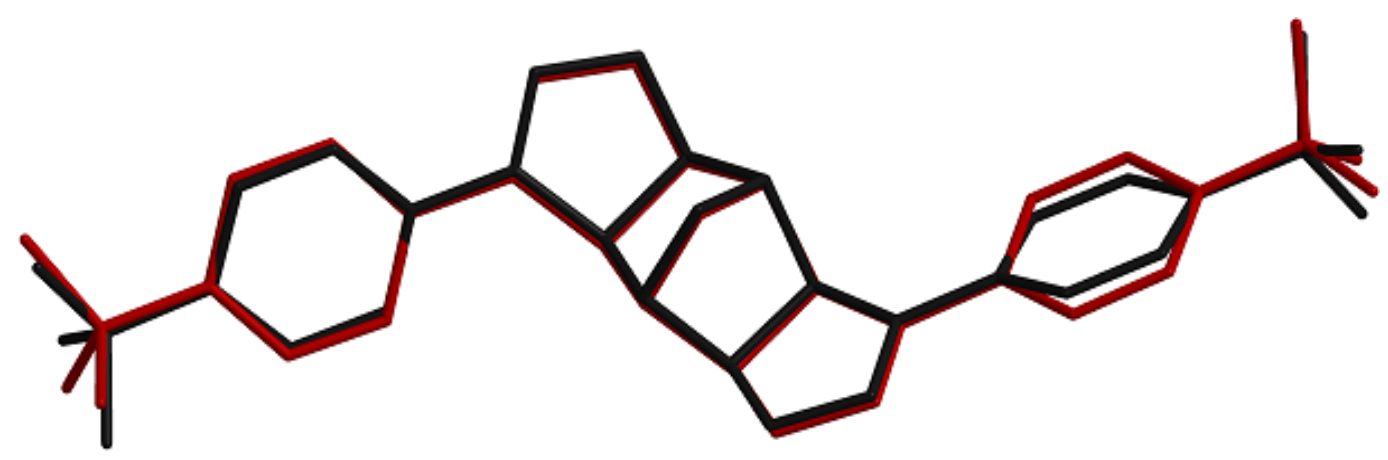

Figure 4. Atom-by-atom superimposition of the calculated structure (DFT/B3LYP76-311G(d,p) (red) on the X-ray structure (black) of the (3) compound
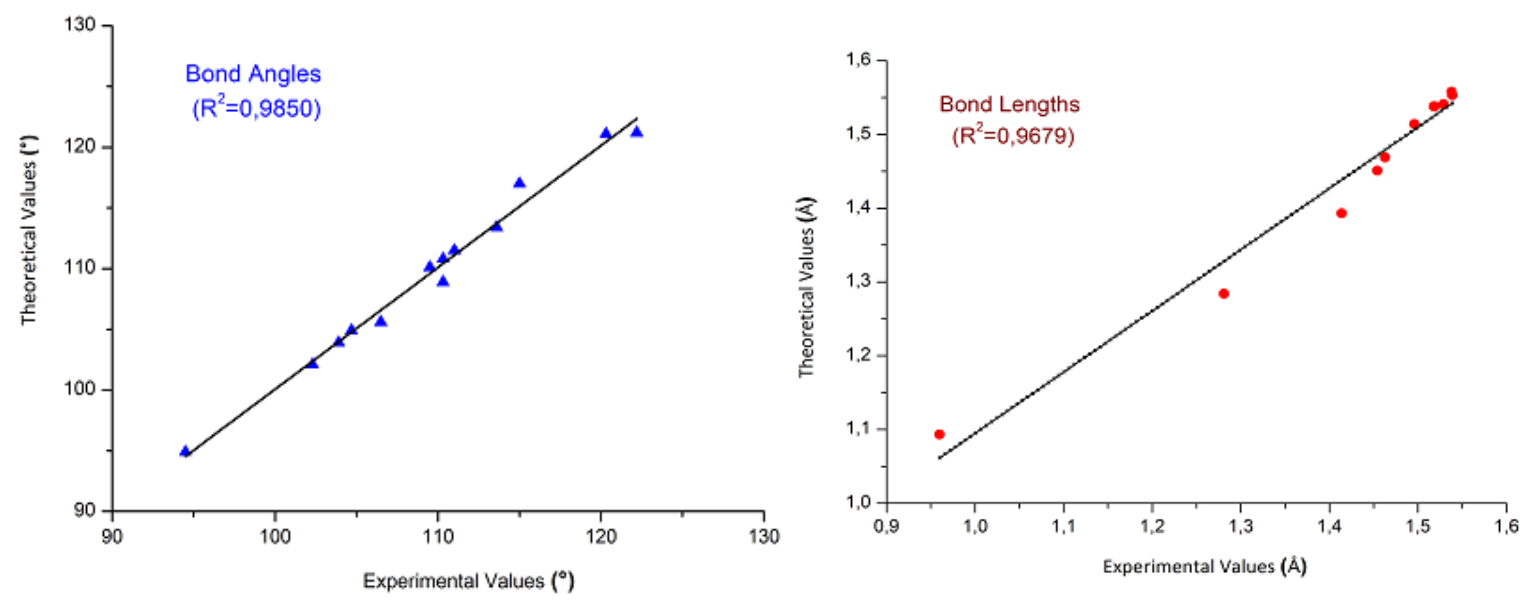

Figure 5. The correlation graphics for geometric parameters of the (3) compound

\subsection{Vibrational Spectral Analysis}

The scaled harmonic vibrational frequencies were calculated with DFT/B3LYP/6-311G(d,p) basis set to determine characteristic functional groups of the (3) compound. The experimental FT-IR spectrum which plotted on the transmittance (\%) against the wavenumber $\left(\mathrm{cm}^{-1}\right)$ is shown in Figure 6.

The (3) compound, which has 67 atoms and 195 fundamental vibrational frequencies, consists isoxazole moiety, bicyclic ring, phenyl and tert-butyl groups. The stretching and bending vibrational assignments in these groups were designated with Gauss View interface program [16], compared with spectral values and results tabulated in Table 3. 


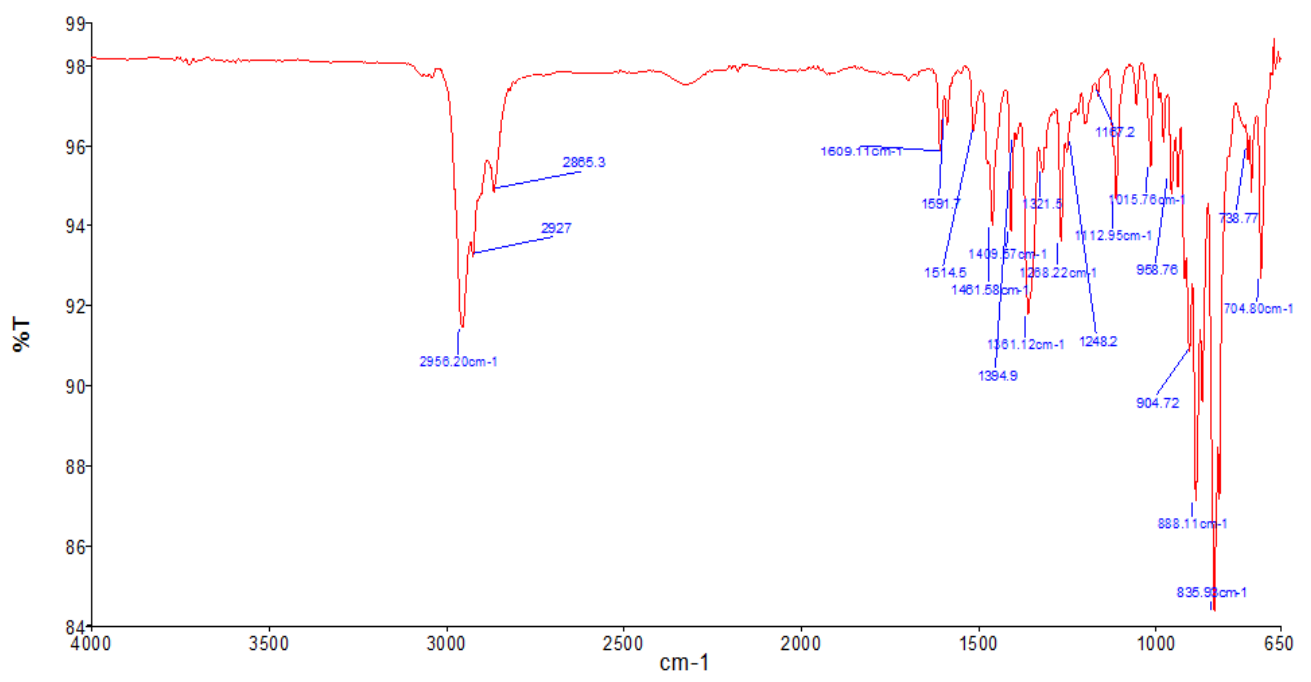

Figure 6. FT-IR spectrum of the (3) compound.

Table 3. Comparison of the experimental and theoretical vibrational spectra analysis of the (3) compound

\begin{tabular}{|c|c|c|}
\hline Assignment & $\begin{array}{c}\text { Experimental FT-IR } \\
\left(\mathrm{cm}^{-1}\right) \text { with } \mathrm{KBr} \\
\end{array}$ & $\begin{array}{c}\text { Calculated (scaled) }\left(\mathrm{cm}^{-1}\right) \\
\text { B3LYP/6-311G }(d, p) \\
\end{array}$ \\
\hline$v_{\mathrm{s}}(\mathrm{C}-\mathrm{H})_{\text {phenyl }}$ & 2956.2 & 3104.6 \\
\hline$v_{\text {as }}(\mathrm{C}-\mathrm{H})_{\text {phenyl }}$ & - & 3089.6 \\
\hline$v_{\mathrm{s}}\left(\mathrm{C}-\mathrm{H}_{2}\right)_{\text {bicyclic }}$ & 2927 & 2983.7 \\
\hline$v_{\text {as }}(\mathrm{C}-\mathrm{H})_{\text {bicyclic }}$ & - & 2965.8 \\
\hline$v_{\mathrm{s}}(\mathrm{C}-\mathrm{H})_{\text {tert-butyl }}$ & 2865.3 & 2933.9 \\
\hline$v(\mathrm{C}=\mathrm{N})_{\text {isoxazole }}$ & 1609.1 & 1587.1 \\
\hline$v(\mathrm{C}-\mathrm{C})_{\text {phenyl }}$ & 1591.7 & 1538.9 \\
\hline$\gamma(\mathrm{C}-\mathrm{H})_{\text {phenyl }}$ & 1514.5 & 1498.6 \\
\hline$\alpha\left(\mathrm{C}-\mathrm{H}_{3}\right)_{\text {tert-butyl }}$ & 1409.5 & 1437.1 \\
\hline$\alpha(\mathrm{C}-\mathrm{H})_{\text {phenyl }}$ & 1394.9 & 1394.1 \\
\hline$\gamma(\mathrm{C}-\mathrm{H})$ phenyl+ isoxazole & 1361.1 & 1330.2 \\
\hline$\omega(\mathrm{C}-\mathrm{H})_{\text {tert-butyl+ bicyclic }}$ & 1248.2 & 1235.4 \\
\hline$\delta(\mathrm{C}-\mathrm{H})_{\text {bicyclic }}$ & 1112.9 & 1100.8 \\
\hline$\beta(\mathrm{CCC})_{\text {phenyl }}$ & 1015.7 & 998.9 \\
\hline$v(\mathrm{~N}-\mathrm{O})_{\text {isoxazole }}$ & 958.7 & 921.4 \\
\hline$\Theta_{\text {bicyclict isoxazole }}$ & 904.7 & 906.2 \\
\hline$\beta_{\text {bicyclic }}$ & 835.9 & 826.2 \\
\hline$\Theta_{\text {phenyl }}$ & 704.8 & 654.3 \\
\hline
\end{tabular}

The C-H stretching vibrations are observed at $2956.2-2865.3 \mathrm{~cm}^{-1}$ in the FT-IR spectrum, 3104.6-2933.9 $\mathrm{cm}^{-1}$ in the theoretical IR spectrum of the (3) compound. C-H stretching vibrations in phenyl ring-a typical C-H stretching in aromatic group-are recorded at $2956.2,3104.6-3089.6 \mathrm{~cm}^{-1}$, at $2927,2983.7-$ $2965.8 \mathrm{~cm}^{-1}$ in bicyclic ring, as spectral and theoretical values. These values are noticeable specific bands in this region and consistent with $3100-3000 \mathrm{~cm}^{-1}$ bandwidth which defined C-H stretching vibrational for cyclic ring and aromatic group [27]. The strong $\mathrm{C}-\mathrm{H}$ stretching vibrational mode is recorded at $2865.3 \mathrm{~cm}^{-1}$ experimentally, $2933.9 \mathrm{~cm}^{-1}$ theoretically in tert-butyl, and the assignments are compatible with the knowledge as strong and weak $\mathrm{C}-\mathrm{H}$ stretching vibrations belong to methyl group are recorded about $2960-2850 \mathrm{~cm}^{-1}$ wavenumber [28, 29]. In the other isoxazole studies, $\mathrm{C}=\mathrm{N}$ stretching band which is characteristic of the isoxazole ring vibrations are observed $1589.6,1588.3 \mathrm{~cm}^{-1}$ for 6$311 \mathrm{G}(\mathrm{d}, \mathrm{p})$ [8], 1586, $1584 \mathrm{~cm}^{-1}$ for $6-31 \mathrm{G}(\mathrm{d}, \mathrm{p})$ and $1579 \mathrm{~cm}^{-1}$ for $6-311+\mathrm{G}(\mathrm{d}, \mathrm{p})$ basis set [26], while this band are recorded at 1609.1 and $1587.1 \mathrm{~cm}^{-1}$ in this study, experimental and computed values, 
respectively. C-H in-plane and out-of plane bending vibrations bands belong to functional groups of the (3) compound are recorded at $1514.5-1112.9 \mathrm{~cm}^{-1}$ for spectral and from 1498.6 to $1100.8 \mathrm{~cm}^{-1}$ for theoretical values. And, $\mathrm{N}-\mathrm{O}$ stretching vibration mode is predicted at $921.4 \mathrm{~cm}^{-1}$, while this mode is stated at 878 and $879 \mathrm{~cm}^{-1}$ in a isoxazolone [30], $977 \mathrm{~cm}^{-1}$ [31] and 923.2-912-6 $\mathrm{cm}^{-1}$ [8] in isoxazole studies. The deformation modes on the functional groups and whole structure are observed in the values below at $906.2 \mathrm{~cm}^{-1}$. We think that predicted vibrational modes and computed frequencies are in compliance with experimental values and similar papers in literature. To make comparison theoretical with experimental results, we have examined correlation graphic and correlation coefficient $\left(\mathrm{R}^{2}\right.$ value is 0.9984 ), correlation graphic shown in Figure 7.

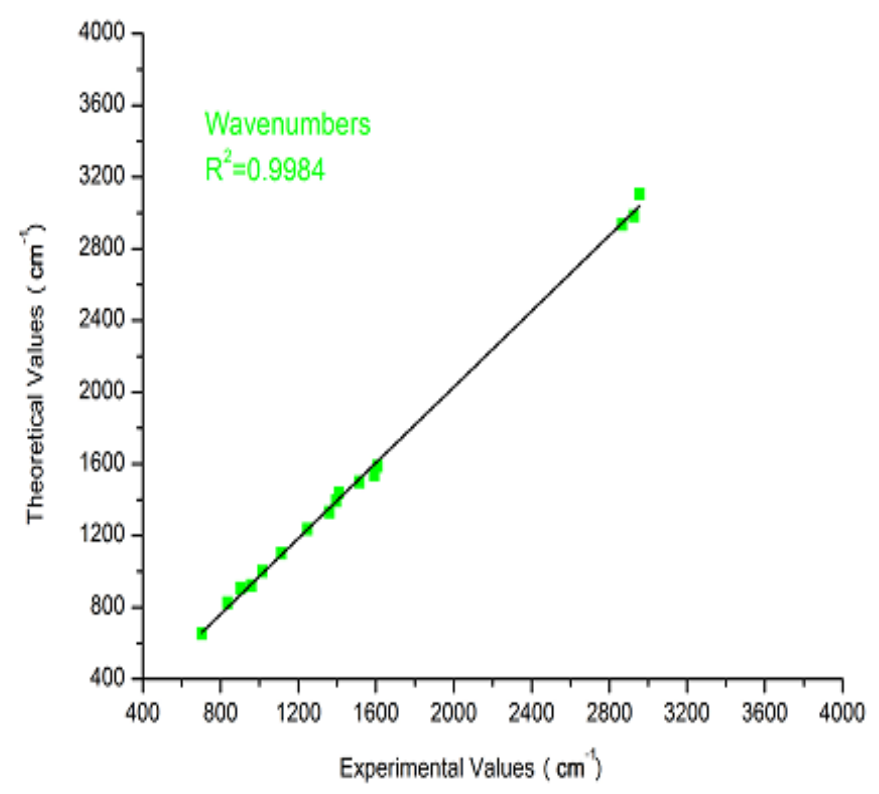

Figure 7. The correlation graphic for experimental and theoretical wavenumbers of the (3) compound

\subsection{NMR Spectral Analysis}

Spectral and theoretical ${ }^{13} \mathrm{C}-\mathrm{NMR}$ and ${ }^{1} \mathrm{H}-\mathrm{NMR}$ chemical shifts values of the (3) compound were recorded within the range of 155.62-26.96 ppm, 163.34-30.18 ppm and 7.64-1.34 ppm, 8.37-1.09 ppm respectively, and these values belong to atoms are shown in Table 4.

As can be seen in the Table 4, C11 atom, which is the bridge atom among the isoxazole and phenyl groups, with the highest chemical shift value in the downfield was observed at $155.62 \mathrm{ppm}, 163.34 \mathrm{ppm}$ for as experimental, theoretical, respectively. So, $\mathrm{C} 11^{\mathrm{i}}$ chemical shift value is $155.50 \mathrm{ppm}$ another highest value. Because the (3) compound has a mirror symmetry and some chemical shift values are very close together for symmetric atoms.

$\mathrm{sp}^{2}$ hybridized $\mathrm{C} 11$ atom having double bond with nitrogen, has shifted in downfield because of decrease of the electron density and weak shielding effect. The phenyl ring atoms, C6, C7, C8, C9 and C10, have chemical shift values special to aromatic ring carbon atoms (100-150 ppm) [32, 33]. They were recorded 126.64-125.54 ppm as experimental, $133.66-130.97 \mathrm{ppm}$ as theoretical. Although C5 atom is a phenyl ring atom, it has slightly higher chemical shift value $(153.72 \mathrm{ppm})$ than the other ring carbon atoms since has substituent of the tert-butyl.

The chemical shift values are belong to aromatic hydrogen $\mathrm{H} 6, \mathrm{H} 7, \mathrm{H} 9$ and $\mathrm{H} 10$ atoms are 7.64-7.45 ppm as spectral values, 8.37 and $7.56 \mathrm{ppm}$ as computed values with GIAO method. These resonance values are in accord with the literature [34] that indicates as $6.0-8.5 \mathrm{ppm}$ for aromatic protons. The H12 atom has higher chemical shift value (4.88 ppm experimentally, $4.92 \mathrm{ppm}$ theoretically) than $\mathrm{H} 13$ atom 
due to attached electronegative oxygen atom. The tert-butyl protons have given low chemical shift values in the up field, these values are confirm that information $\mathrm{sp}^{3}$ hybridized methyl group protons are assigned at 0-2 ppm [28].

${ }^{13} \mathrm{C}-\mathrm{NMR}$ and ${ }^{1} \mathrm{H}-\mathrm{NMR}$ spectrums of the (3) compound are shown in Figure 8. To compare the experimental and theoretical values, the correlation graphics were examined, $\mathrm{R}^{2}$ value is 0.9985 for ${ }^{13} \mathrm{C}$ NMR, 0.9936 for ${ }^{13} \mathrm{C}-\mathrm{NMR}$ shown in Figure 9.

Table 4. Experimental and theoretical ${ }^{13} \mathrm{C}-\mathrm{NMR}$ and ${ }^{1} \mathrm{H}-\mathrm{NMR}$ isotropic chemical shift values for the (3) compound

\begin{tabular}{|c|c|c|c|c|c|}
\hline Atom & $\begin{array}{c}\text { Experimental } \\
\text { chemical shift } \\
\text { values } \\
(\text { ppm }) / C D C l_{3}\end{array}$ & $\begin{array}{c}\text { Theoretical } \\
\text { chemical shift } \\
\text { values } \\
(\text { ppm)/B3LYP }\end{array}$ & Atom & $\begin{array}{c}\text { Experimental } \\
\text { chemical shift } \\
\text { values } \\
(\text { ppm }) / C D C l_{3}\end{array}$ & $\begin{array}{c}\text { Theoretical } \\
\text { chemical } \\
\text { shift values } \\
\text { (ppm)/B3LYP }\end{array}$ \\
\hline $\mathrm{C} 1 / \mathrm{C} 1^{\mathrm{i}}$ & 31.16 & 34.70 & $\mathrm{C} 14 / \mathrm{C} 14^{\mathrm{i}}$ & $50.78 / 46.06$ & 53.06 \\
\hline $\mathrm{C} 2 / \mathrm{C} 2^{\mathrm{i}}$ & 31.16 & 30.18 & C15 & 26.96 & 30.18 \\
\hline $\mathrm{C} 3 / \mathrm{C} 3^{\mathrm{i}}$ & 31.16 & 34.72 & $\mathrm{H} 1 / \mathrm{H}^{\mathrm{i}}$ & 1.34 & $1.15-1.20-1.63$ \\
\hline $\mathrm{C} 4 / \mathrm{C}^{\mathrm{i}}$ & 34.89 & 42.20 & $\mathrm{H} 2 / \mathrm{H}{ }^{\mathrm{i}}$ & 1.34 & $1.09-1.54-1.56$ \\
\hline $\mathrm{C} 5 / \mathrm{C} 5^{\mathrm{i}}$ & $153.72 / 153.61$ & 162.47 & $\mathrm{H} 3 / \mathrm{H}^{\mathrm{i}}$ & 1.34 & $1.13-1.18-1.64$ \\
\hline $\mathrm{C} 6 / \mathrm{C}^{\mathrm{i}}$ & 125.54 & 130.97 & H6/H6 ${ }^{\mathrm{i}}$ & 7.45 & 7.57 \\
\hline $\mathrm{C} 7 / \mathrm{C}^{\mathrm{i}}$ & 125.79 & 132.41 & $\mathrm{H} 7 / \mathrm{H}^{\mathrm{i}}$ & 7.64 & 8.37 \\
\hline $\mathrm{C} 8 / \mathrm{C}^{\mathrm{i}}$ & 126.49 & 133.48 & H9/H9i & 7.64 & 7.56 \\
\hline $\mathrm{C} 9 / \mathrm{C} 9^{\mathrm{i}}$ & 125.87 & 132.74 & $\mathrm{H} 10 / \mathrm{H} 10^{\mathrm{i}}$ & 7.45 & 7.80 \\
\hline $\mathrm{C} 10 / \mathrm{C} 10^{\mathrm{i}}$ & 126.64 & 133.66 & $\mathrm{H} 12 / \mathrm{H} 12^{\mathrm{i}}$ & $4.84 / 4.75$ & 4.92 \\
\hline $\mathrm{C} 11 / \mathrm{C} 11^{\mathrm{i}}$ & $155.62 / 155.50$ & 163.34 & $\mathrm{H} 13 / \mathrm{H} 13^{\mathrm{i}}$ & $3.83 / 3.65$ & 3.56 \\
\hline $\mathrm{C} 12 / \mathrm{C} 12^{\mathrm{i}}$ & $86.36 / 83.27$ & 94.44 & $\mathrm{H} 14 / \mathrm{H} 14^{\mathrm{i}}$ & 2.95 & 2.89 \\
\hline $\mathrm{C} 13 / \mathrm{C} 13^{\mathrm{i}}$ & $56.77 / 52.85$ & 58.95 & $\mathrm{H} 15 \mathrm{a} / \mathrm{H} 15 \mathrm{~b}$ & 1.59 & 1.51 \\
\hline
\end{tabular}

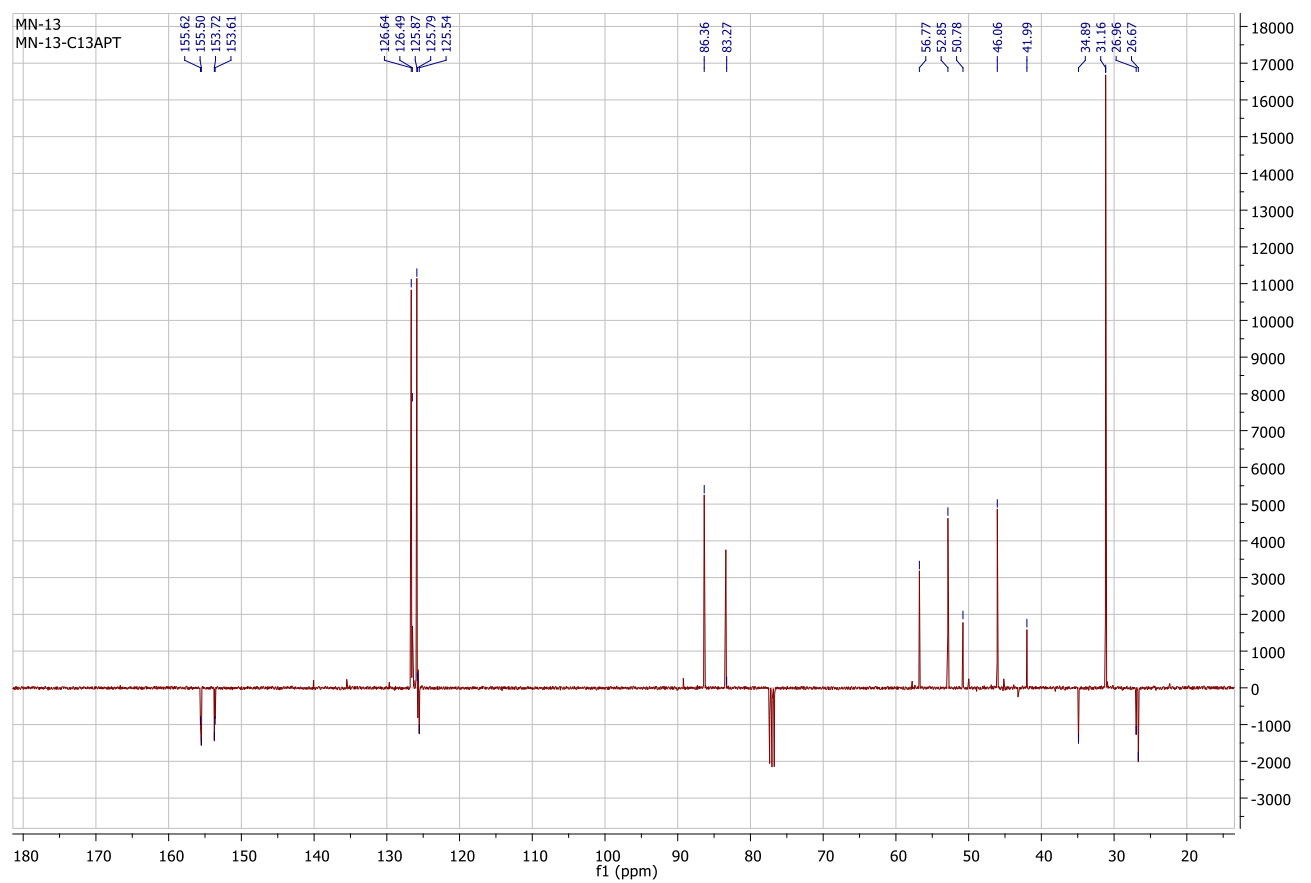

a) 


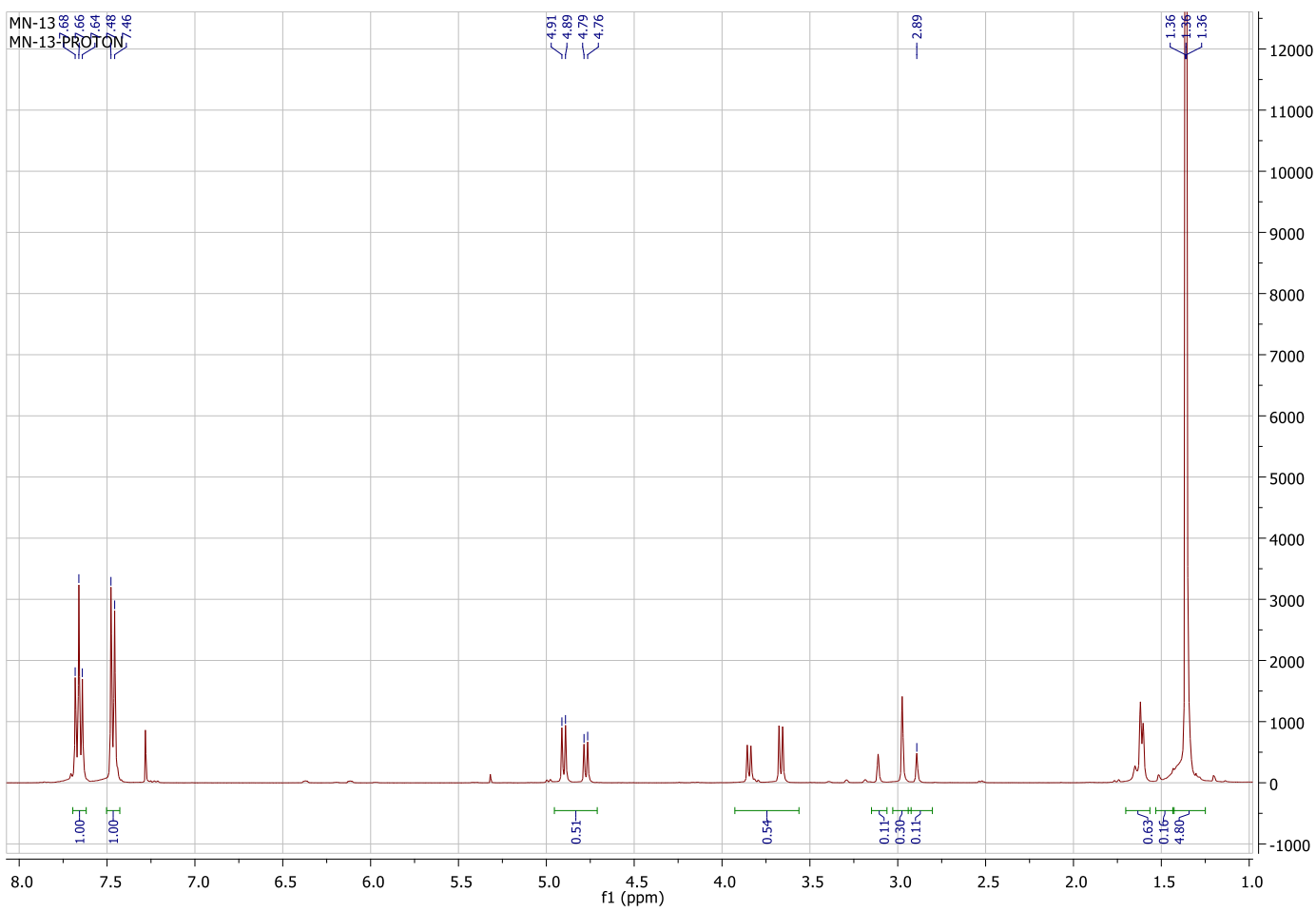

b)

Figure 8. a) ${ }^{13} \mathrm{C}-\mathrm{NMR}$, b) ${ }^{1} \mathrm{H}-\mathrm{NMR}$ spectrum of the (3) compound
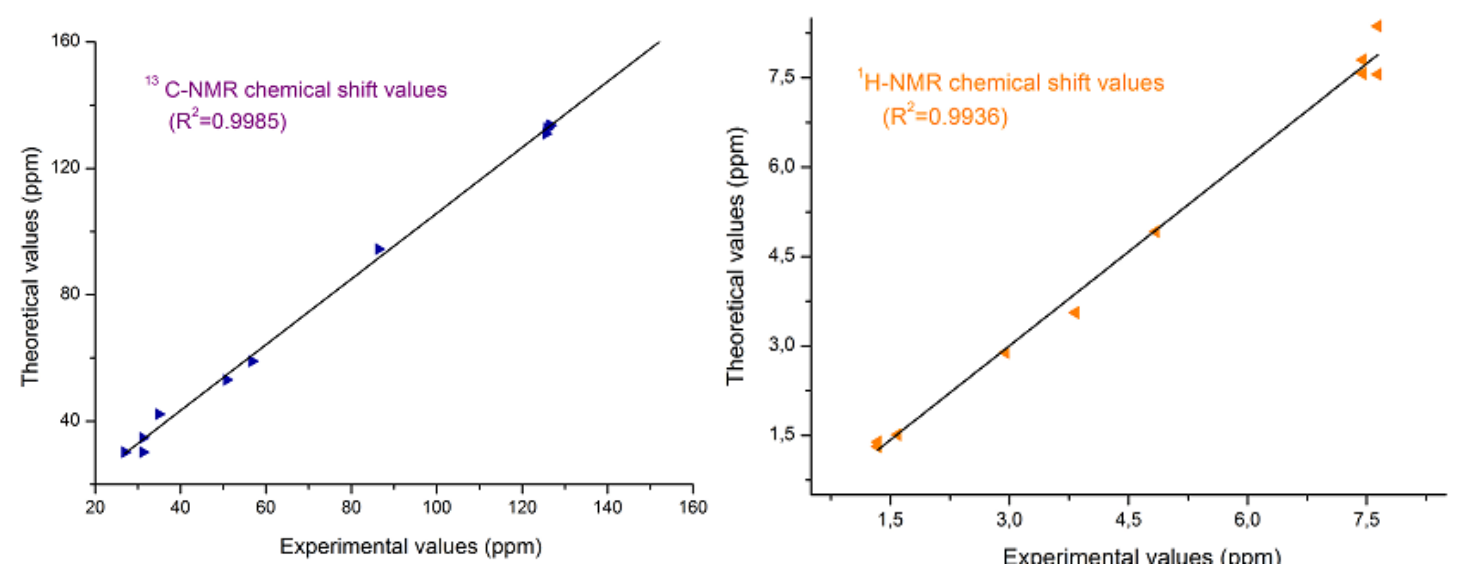

Figure 9. The correlation graphics for experimental and theoretical chemical shift values of the (3) compound

\subsection{UV-Vis Spectral and FMOs Analysis}

UV-Vis spectral analysis of the (3) compound was realized with TD-DFT/B3LYP/6-311G(d,p) in gas phase and different solvent media such as DMSO, THF and methanol. The absorption wavelengths which recorded as spectral result and theoretical prediction, excitation energies $(\mathrm{eV})$ and oscillator strengths $(f)$ are listed in Table 5. The electronic absorption spectrum which obtained in three different solvent is given Figure 10. The effect solvent which has different polarity are showed the effect maximum absorption wavelengths values, for instance; methanol is a polar and protic solvent and transitions are observed at lower wavelengths. 
Table 5. The experimental and calculated UV-Visible parameters of the (3) compound

\begin{tabular}{|c|c|c|c|c|c|}
\hline & $\begin{array}{c}\text { Experimental } \\
\text { Wavelength } \\
\lambda_{\max }(\mathrm{nm}) \\
\end{array}$ & $\begin{array}{c}\text { Theoretical } \\
\text { Wavelength } \\
\lambda_{\max }(\mathrm{nm})\end{array}$ & $\begin{array}{c}\text { Excitation Energy } \\
(e V)\end{array}$ & $\begin{array}{c}\text { Oscillator } \\
\text { Strength } \\
(f) \\
\end{array}$ & $\begin{array}{l}\text { Probable Orbital } \\
\text { Transition }\end{array}$ \\
\hline \multirow{3}{*}{ Gas Phase } & & 295.77 & 4.19 & 0.001 & $\mathrm{HOMO} \rightarrow \mathrm{LUMO}(97 \%)$ \\
\hline & & 284.90 & 4.35 & 0.021 & $\begin{array}{l}\mathrm{HOMO}-1 \rightarrow \mathrm{LUMO}(55 \%) \\
\mathrm{HOMO} \rightarrow \mathrm{LUMO}+1(43 \%)\end{array}$ \\
\hline & & 280.75 & 4.41 & 1.172 & $\begin{array}{l}\text { HOMO } 1 \rightarrow \text { LUMO }(42 \%) \\
\text { HOMO } \rightarrow \text { LUMO }+1(54 \%)\end{array}$ \\
\hline \multirow{3}{*}{$T H F$} & 392.9 & 296.48 & 4.18 & 0.001 & $\mathrm{HOMO} \rightarrow \operatorname{LUMO}(98 \%)$ \\
\hline & 295.7 & 284.97 & 4.35 & 0.024 & $\begin{array}{l}\text { HOMO- } 1 \rightarrow \text { LUMO }(56 \%) \\
\text { HOMO } \rightarrow \text { LUMO }+1(42 \%)\end{array}$ \\
\hline & 274.4 & 282.04 & 4.39 & 1.205 & $\begin{array}{l}\text { HOMO- } \rightarrow \text { LUMO }(42 \%) \\
\text { HOMO } \rightarrow \text { LUMO }+1(55 \%)\end{array}$ \\
\hline \multirow{3}{*}{$\mathrm{MeOH}$} & 265.25 & 296.05 & 4.18 & 0.013 & $\mathrm{HOMO} \rightarrow \mathrm{LUMO}(97 \%)$ \\
\hline & 221.99 & 284.91 & 4.35 & 0.022 & $\begin{array}{l}\mathrm{HOMO}-1 \rightarrow \mathrm{LUMO}(55 \%) \\
\mathrm{HOMO} \rightarrow \mathrm{LUMO}+1(43 \%)\end{array}$ \\
\hline & 217.02 & 281.39 & 4.40 & 1.183 & $\begin{array}{l}\text { HOMO- } \rightarrow \text { LUMO }(42 \%) \\
\text { HOMO } \rightarrow \text { LUMO }+1(55 \%)\end{array}$ \\
\hline \multirow{3}{*}{$D M S O$} & 379.80 & 296.38 & 4.18 & 0.001 & $\mathrm{HOMO} \rightarrow \mathrm{LUMO}(98 \%)$ \\
\hline & 300.29 & 284.92 & 4.35 & 0.029 & $\begin{array}{l}\text { HOMO } 1 \rightarrow \text { LUMO }(57 \%) \\
\text { HOMO } \rightarrow \text { LUMO }+1(41 \%)\end{array}$ \\
\hline & 270.20 & 282.13 & 4.39 & 1.204 & $\begin{array}{l}\mathrm{HOMO}-1 \rightarrow \mathrm{LUMO}(40 \%) \\
\mathrm{HOMO} \rightarrow \mathrm{LUMO}+1(57 \%)\end{array}$ \\
\hline
\end{tabular}

The maximum absorption wavelengths values are related to $n \rightarrow \pi^{*}$ transition of around isoxazole moiety probably due to the presence of carbon-nitrogen double bond, other wavelengths can be concerned with $\pi \rightarrow \pi^{*}$ transitions of aromatic groups.

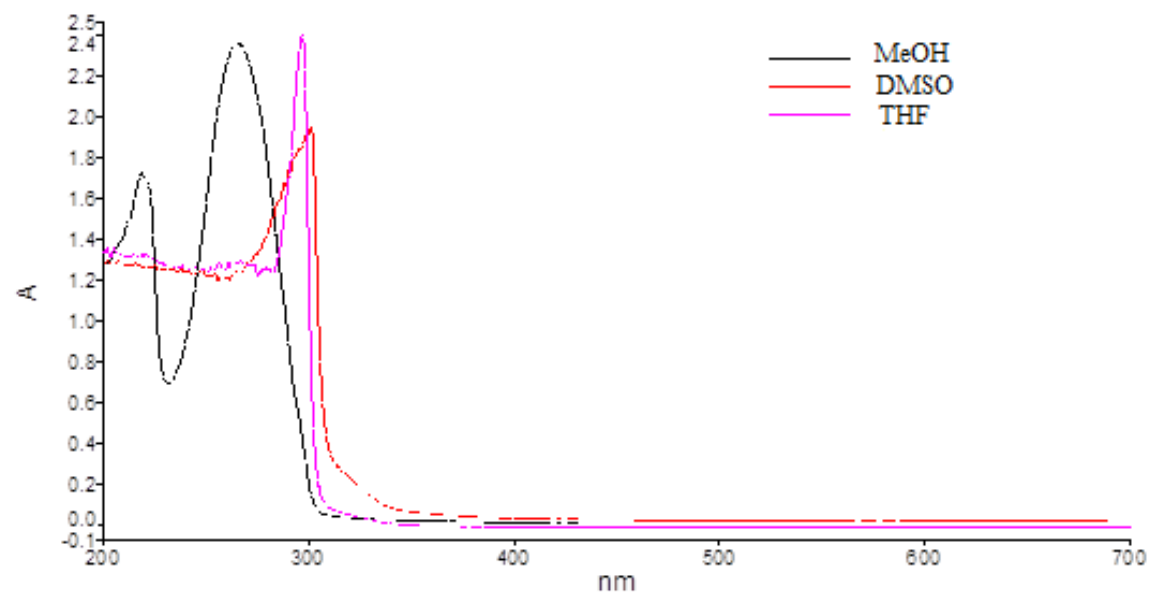

Figure 10. UV-Vis spectrum of the (3) compound

Frontier molecular orbitals' energies of the (3) compound were obtained using B3LYP method with 6$311 \mathrm{G}(\mathrm{d}, \mathrm{p})$ basis set. The highest occupied molecular orbital-HOMO and the lowest unoccupied molecular orbital-LUMO and HOMO-1, LUMO+1 distributions for the structure and energy values are shown in Figure 11. 


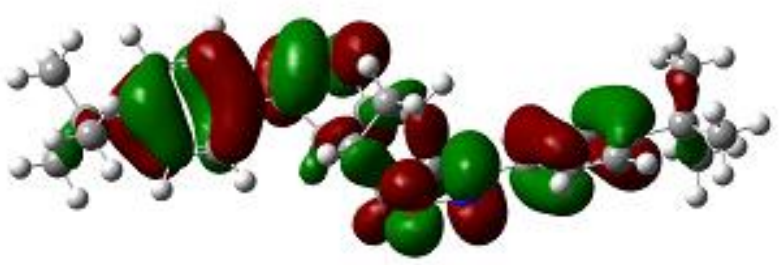

$E_{\text {номо }}=-6.18 \mathrm{eV}$

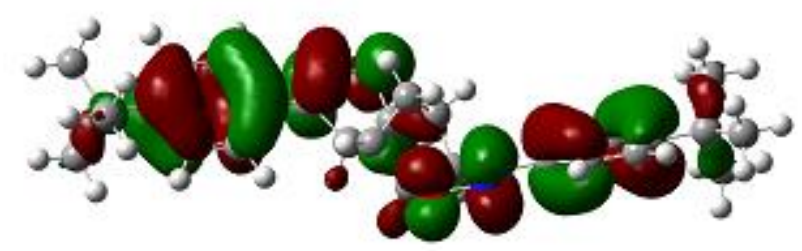

$E_{\text {номо-1 }}=-6.35 \mathrm{eV}$

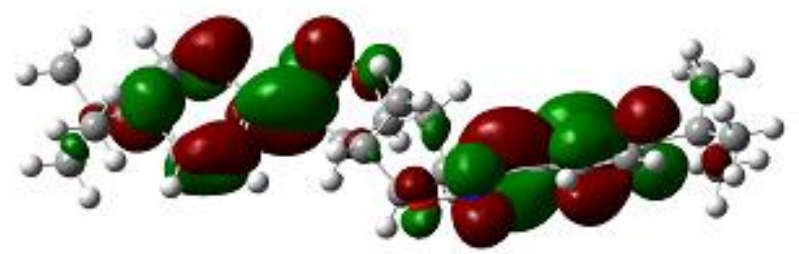

$E_{L U M O+1}=-1.43 \mathrm{eV}$

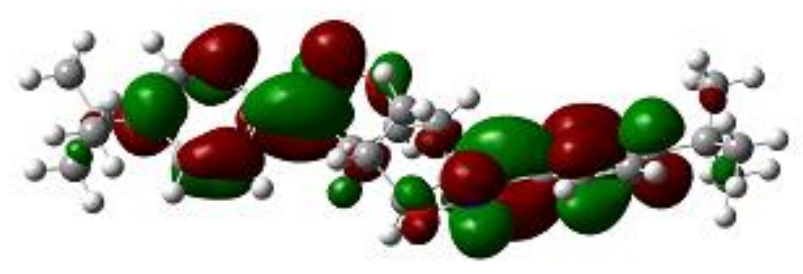

$E_{L U M O}=-1.57 \mathrm{eV}$

Figure 11. The frontier molecular orbitals and energy levels of the (3) compound in gas phase

The positive and negative phases seen in this Figure 11, which are red and green colour distributions and represent these phases in molecular orbital wave function, are distributed symmetrically over the whole structure except tert-butyl group. HOMO has located at the isoxazole moiety and phenyl groups, perhaps a little around bicyclic atoms but asymmetrically and except methylene group on the bridge. LUMO has settled over the isoxazole moiety and phenyl groups is quite satisfactory symmetrical for all positive and negative phases but excluding bicyclic ring. So, energy value of the band gap is calculated as $\Delta \mathrm{E}=\mathrm{E}_{\mathrm{HOMO}}-\mathrm{E}_{\mathrm{LUMO}}=4.61 \mathrm{eV}$ and it means that the compound has quite stable feature $[35,36]$.

HOMO has a nucleophilic characteristic which can donate electron, while LUMO can be acceptor electron as it has an electrophilic characteristic. HOMO-LUMO analysis helps to determinate electrical and optical properties for the chemical reactions, electrical transport properties and the state electronic transition at the UV-Vis spectra [8, 37, 38]. We benefited from these orbitals' energy values when examining the chemical reactivity features of the (3) compound in different solvent media. In addition, HOMO-LUMO energy values are used in calculation of the global reactivity descriptors which act as a bridge between stability of the structures and global chemical reactivity $[8,39]$. Also this information about fundamental properties of the chemical reactivity such as ionization potential, electron affinity, electronegativity, chemical potential, global hardness and global softness etc. [40]. Energy values belong to frontier molecular orbitals can be considered as the important starting point to determine these parameters.

The ionization potential is the minimum energy required to remove an electron from an atom or molecule and can be expressed as, $I=-E_{\text {номо }}(I$; vertical ionization potential for DFT method). According to Koopman's Theory [41], electron affinity $(A)$ is described as the change in energy when is an electron added to a neutral atom in the gas phase and is given as, $A=-E_{L U M O}$. Electronegativity $(\chi)$ and chemical hardness $(\eta)[42,43]$ help to predict about the formation of chemical bonds and the physical, chemical properties of the compound [44], can be calculated as $\chi=(I+A) / 2$ and $\eta=(I-A) / 2$. Similarly, other global reactivity descriptors are chemical softness $(s)$ [44], electronic chemical potential $(\mu)$ as characteristic of electronegativity of compounds [41b, 45] and electrophilicity index $(\omega)$ [46] which defined as $s=1 / 2 \eta$, $\mu=-(I+A) / 2, \omega=\mu^{2} / 2 \eta$, respectively. All of these concepts, total energies, dipole moments were 
computed at gas phase $(\varepsilon=1)$ and at tetrahydrofuran $(\varepsilon=7.42)$, methanol $(\varepsilon=32.63)$, dimethyl sulfoxide $(\varepsilon=46.82)$ phase for UV-Vis region, the results are given in Table 6 .

\begin{tabular}{|c|c|c|c|c|}
\hline & $\begin{array}{c}\text { Gas } \\
(\varepsilon=1)\end{array}$ & $\begin{array}{c}\text { THF } \\
(\varepsilon=7.42)\end{array}$ & $\mathrm{MeOH}(\varepsilon=32.61)$ & $D M S O(\varepsilon=46.82)$ \\
\hline ЕтОTAL & -1385.62839088 & -1385.62661374 & -1385.62834116 & -1385.62868789 \\
\hline$\mu_{\text {Dipole }}$ & 2.9151 & 2.7256 & 2.9025 & 2.9193 \\
\hline $\mathrm{E}_{\text {номо }}$ & -6.1814 & -6.1618 & -6.1795 & -6.1812 \\
\hline $\mathrm{E}_{\text {LUMO }}$ & -1.5789 & -1.5618 & -1.5776 & -1.5789 \\
\hline$I$ & 6.1814 & 6.1618 & 6.1795 & 6.1812 \\
\hline$A$ & 1.5789 & 1.5618 & 1.5776 & 1.5789 \\
\hline$\chi$ & 3.8801 & 3.8618 & 3.8785 & 3.8800 \\
\hline$\eta$ & 2.3012 & 2.3000 & 2.3009 & 2.3011 \\
\hline$s$ & 0.2172 & 0.2173 & 0.2173 & 0.2172 \\
\hline$\mu$ & -3.8801 & -3.8618 & -3.8785 & -3.8800 \\
\hline$\omega$ & 3.2711 & 3.2420 & 3.2688 & 3.2711 \\
\hline
\end{tabular}

Total Energy (a.u), Dipole Moment (debye), Ionization potential (eV), Electron affinity $(\mathrm{eV})$,

Electronegativity $(\mathrm{eV})$, Chemical hardness $(\mathrm{eV})$, Chemical softness $\left(\mathrm{eV}^{-1}\right)$, Electronic chemical potential $(\mathrm{eV})$, Electrophilicity index $(\mathrm{eV})$

It can be seen from Table 6 that the total energy of the (3) compound decreases with increasing polarity of the solvent, as dipole moment, other structure parameters and stability of the compound increases accordingly applied CPCM method.

\subsection{Molecular Electrostatic Potential Analysis}

The molecular electrostatic potential map of the (3) compound was generated at the B3LYP/6-311G(d,p) level. In that map, the region of the most negative electrostatic potential represents in red, blue the most positive electrostatic potential and green zero potential [47]. MEP helps with electrophilic and nucleophilic attack character of the molecules; namely, negative regions-red coloured are associated with electrophilic, and positive regions-blue coloured with nucleophilic attack.

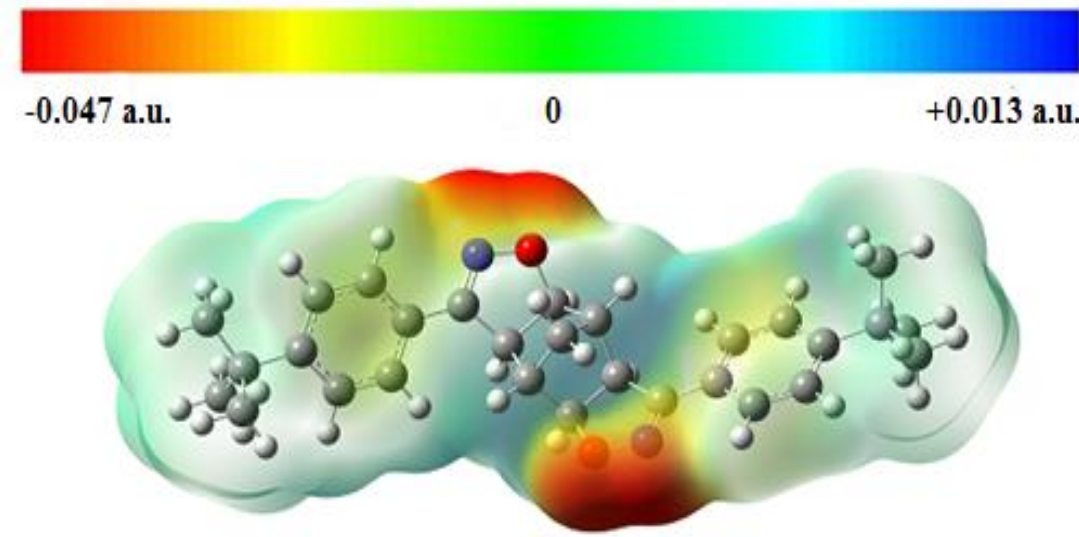

Figure 12. The molecular electrostatic potential map of the (3) compound

The MEP of the title compound is given in Figure 12, which has colour codes from red to blue, represents a potential distribution in the range of -0.047 a.u. to 0.013 a.u. The values of negative electrostatic potential are located on around isoxazole moiety, particularly nitrogen (with -0.0313 a.u.) and oxygen atoms (with -0.0326 a.u.), which are preferred site for electrophilic attack, while positive electrostatic 
potential around bicyclic group, especially hydrogen atoms (with 0.0034 a.u.), which is preferred site for nucleophilic attack.

\section{CONCLUSION}

3,7-bis(4-(tert-butyl)phenyl)-3a,4,4a,7a,8,8a-hexahydro-4,8-methanobenzo[1,2-d:4,5-d']diisoxazole compound which is one of the bisisoxaoline derivative of norbornadien, synthesized and characterized with spectral analysis by FT-IR, ${ }^{1} \mathrm{H}-\mathrm{NMR},{ }^{13} \mathrm{C}-\mathrm{NMR}, \mathrm{UV}-\mathrm{Vis}$ and X-ray crystallographic technique. The theoretical investigation were performed with DFT/B3LYP/6-311G $(\mathrm{d}, \mathrm{p})$ basis set over the ground state. And, the results of spectral analysis were compared with computed molecular geometric parameters, vibrational frequencies, ${ }^{1} \mathrm{H}-\mathrm{NMR}$ and ${ }^{13} \mathrm{C}-\mathrm{NMR}$ chemical shifts. The theoretical geometric structure parameters such as bond lengths and angles, computed frequencies and chemical shifts values are in compliance with experimental values and similar papers or other isoxazole studies $[8,23,26,30$, 31]. And also, electronic absorption spectrum analysis of the (3) compound was examined both experimental and with TD-DFT/B3LYP/6-311G(d,p)/CPCM methods in gas phase and different solvent media such as DMSO, THF and $\mathrm{MeOH}$. The total energy, dipol moment and chemical stability parameters get changed with the different solvent polarity.

Also, we evaluated molecular geometry of isoxazoline ring position; exo-endo. The experimental NMR results have showed symmetrical same cyclo-addition such as both ring exo-exo or endo-endo, so we have described exo molecular geometry depend on spin-spin interaction on ${ }^{1} \mathrm{H}-\mathrm{NMR}$ values. X-ray analysis results showed exo molecular geometry position and the comparisons with optimized geometry are reported in this work.

FMOs, MEP and thermodynamic analysis were realized to obtained information about nucleophilic or electrophilic characteristic, chemical activity properties such as ionization potential, electron affinity, electronegativity, chemical potential, global hardness and global softness, electronic transition at the UV-Vis spectra, electrostatic potential distribution on the molecule surface of the title compound. We hope that these consequences will create an infrastructure for researchers carrying out other isoxazole derivatives or similar studies and can be used for further analyses.

\section{ACKNOWLEDGMENTS}

This study was financially supported by the Amasya University Research Fund (Project No:FMB-BAP 054/085). The (3) compound has been identified in the AUMAULAB Central Laboratory in Amasya University, Turkey. Also, the authors acknowledge Scientific and Technological Research Application and Research Center, Sinop University, Turkey, for the use of the Bruker D8 QUEST diffractometer.

\section{REFERENCES}

[1] a) Padwa A. 1,3-Dipolar Cycloaddition Chemistry II. 3rd. Ed. New York, NY, USA: Wiley Press, 1984.

b) Padwa A. Synthetic Application of 1,3-dipolar Cycloaddition Chemistry Toward Heterocycles and Natural Products. 3rd. Ed. New York NY, USA: Wiley Press, 2001.

[2] a)Kaur K, Kumar V, Sharma AK, Gupta GK. Isoxazoline containing natural products as anticancer agents: A Review. Eur J Med Chem. 2014; 77:121-33.

b)Pekka KP, Tuomas O, Mikael P, Jorma JP, Janne AI, Reino L, Juha TP. Design, Synthesis, and Biological Evaluation of Nonsteroidal Cycloalkane[d]isoxazole-Containing Androgen Receptor Modulators. J. Med Chem 2012; 55 (14): 6316-6327.

[3] Bolvig T, Larsson OM, Pickering DS, Nelson N, Falch E, Krogsgaard-Larsen P, Schousboe A. Action of bicyclic isoxazole GABA analogues on GABA transporters and its relation to anticonvulsant activity. Eur J Pharmacol. 1999; 375(1-3):367-74. 
[4] Tangallapally RP, Yendapally R, Daniels AJ, Lee REB, Lee RE. Nitrofurans as Novel Antituberculosis Agents: Identification, Development and Evaluation. Curr Top Med Chem 2007; 7:509526.

[5] Rakesh DS, Lee RB, Tangallapally RP, Lee RE.Synthesis, optimization and structure-activity relationships of 3,5-disubstituted isoxazolines as new anti-tuberculosis agents. Eur J Med Chem 2009; 44:460-472.

[6] Werner A. Über die Raumliche Anordnung der Atome in Stick Stoff Haltisen Molekülen. Berichte 1890; 23:11-30.

[7] a)Tranmer GK, MolybdenumWT. Mediated Cleavage Reactions of Isoxazoline Rings Fused in Bicyclic Frameworks. Org. Lett 2002; 4 (23): 4101-4104

b)Murphy JJ, Hamilton JG, Paton R M.Synthesis and ring opening metathesis polymerisation of isoxazolino and isoxazolidino-norbornenes. Polymer 2006; 47 (10): 3292-3297.

[8] Eryılmaz S, Gül M, İnkaya E, İdil Ö, Özdemir Namık. Synthesis, Crystal Structure Analysis, Spectral Characterization, Quantum Chemical Calculations, Antioxidant and Antimicrobial Activity of 3-(4chlorophenyl)-3a,4,7,7a-tetrahydro-4,7-methanobenzo[d]isoxazole. J Mol Struct 2016; 1122: 219-233.

[9] Stoe\&Cie, X-AREA (Version 1.18), Stoe\&Cie GmbH, Darmstadt, Germany, 2002.

[10] Sheldrick GM. SHELXS-97. Program for the Solution of Crystal Structures. University of Gottingen. 1997.

[11] Farrugia LJ. J Appl Crystallogr 1999; 30: 837-838.

[12] Sheldrick GM. Acta Crystallogr 2015; C71: 3-8.

[13] Stoe\&Cie, X-RED (Version 1.04), Stoe\&Cie GmbH, Darmstadt, Germany, 2002.

[14] Spek AL. Acta Crystallogr D 2009; 65: 148-155.

[15] Gaussian 09, Revision E.01, Frisch, M. J.; Trucks, G. W.; Schlegel, H. B.; Scuseria, G. E.; Robb, M. A.; Cheeseman, J. R.; Scalmani, G.; Barone, V.; Mennucci, B.; Petersson, G. A.; Nakatsuji, H.; Caricato, M.; Li, X.; Hratchian, H. P.; Izmaylov, A. F.; Bloino, J.; Zheng, G.; Sonnenberg, J. L.; Hada, M.; Ehara, M.; Toyota, K.; Fukuda, R.; Hasegawa, J.; Ishida, M.; Nakajima, T.; Honda, Y.; Kitao, O.; Nakai, H.; Vreven, T.; Montgomery, J. A., Jr.; Peralta, J. E.; Ogliaro, F.; Bearpark, M.; Heyd, J. J.; Brothers, E.; Kudin, K. N.; Staroverov, V. N.; Kobayashi, R.; Normand, J.; Raghavachari, K.; Rendell, A.; Burant, J. C.; Iyengar, S. S.; Tomasi, J.; Cossi, M.; Rega, N.; Millam, J. M.; Klene, M.; Knox, J. E.; Cross, J. B.; Bakken, V.; Adamo, C.; Jaramillo, J.; Gomperts, R.; Stratmann, R. E.; Yazyev, O.; Austin, A. J.; Cammi, R.; Pomelli, C.; Ochterski, J. W.; Martin, R. L.; Morokuma, K.; Zakrzewski, V. G.; Voth, G. A.; Salvador, P.; Dannenberg, J. J.; Dapprich, S.; Daniels, A. D.; Farkas, Ö.; Foresman, J. B.; Ortiz, J. V.; Cioslowski, J.; Fox, D. J. Gaussian, Inc., Wallingford CT, 2009.

[16] GaussView, Version 5, Dennington, Roy; Keith, Todd; Millam, John. Semichem Inc., Shawnee Mission, KS, 2009.

[17] a)Becke AD.Density-functional exchange-energy approximation with correct asymptotic behavior. J Chem Phys 1988; 38: 3098-3100.

b)Becke AD.Density-Functional Thermochemistry. I. The Effect of the Exchange-Only Gradient Correction. J Chem Phys1992; 96: 2155-2160.

c)Becke AD.Density functional thermochemistry III. The role of exact exchange. J Chem Phys 1993; 98: 5648-5652. 
[18] Ditchfield R,Hehre WJ, Pople JA.Self-Consistent Molecular-Orbital Methods. IX. An Extended Gaussian-Type Basis for Molecular-Orbital Studies of Organic Molecules J Chem Phys1971; 54: 724728.

[19] Lee C, Yang CW, Parr R.Development of the Colle-Salvetti correlation-energy formula into a functional of the electron density. Phys Rev1988; 37: 785-789.

[20] Merrick JP, Moran D, Radom L. An Evaluation of Harmonic Vibrational Frequency Scale Factors. J Phys Chem A 2007; 111: 11683-11700.

[21] a)London F.Théorie quantique des courants interatomiques dans les combinaisons aromatiques. $\mathbf{J}$ Phys Radium 1937; 8: 397-409.

b)McWeeny R. Perturbation Theory for the Fock-Dirac Density Matrix Phys Rev 1962; 126: 1028.

c)Ditchfield R. Self-consistent perturbation theory of diamagnetism.Mol Phys 1974; 27: 789-807.

d)Wolinski K, Hilton JF, Pulay P. Efficient implementation of the gauge-independent atomic orbital method for NMR chemical shift calculations. J Am Chem Soc 1990; 112: 8251-8260.

e)Cheeseman JR, Trucks GW, Keith TA, Frisch MJ. A comparison of models for calculating nuclear magnetic resonance shielding tensors. J Chem Phys 1996; 104: 5497-5509.

[22] Barone V, Cossi M. Quantum calculation of molecular energies and energy gradients in solution by a conductor solvent model. J Phys Chem A 1998; 102: 1995-2001.

[23] Jin YX, Zhong AG, Ge CH, Pan FY, Yang JG, Wu Y, Xie M, Feng HW. A novel difunctional acylhydrazone with isoxazole and furan heterocycles: Syntheses, structure, spectroscopic properties, antibacterial activities and theoret ical studies of (E)-N0 -(furan-2-ylmethylene)-5-methylisoxazole-4carbohydrazide. J Mol Struct 2012; 1010: 190-196.

[24] Tamer Ö, Avcı BS, Avcı D, Nebioglu M, Atalay Y, Çoşut B.Synthesis, molecular structure, spectral analysis and nonlinear optical studies on 4-(4-bromophenyl)-1-tert-butyl-3-methyl-1H-pyrazol-5amine: A combined experimental and DFT approach.J Mol Struct 2016; 1106: 89-97.

[25] Dege N, Senyüz N, Batı H, Günay N, Avcı D, Tamer O, Atalay Y. The synthesis, characterization and theoretical study on nicotinic acid [1-(2,3-dihydroxyphenyl)methylidene]hydrazide. Spectrochim Acta A 2014; 120: 323-331.

[26] Eryılmaz S, Gül M, İnkaya E, Taş M. Isoxazole Derivatives of Alpha-pinene Isomers: Synthesis, Crystal Structure, Spectroscopic Characterization (FT-IR/NMR/GC-MS) and DFT Studies. J Mol Struct 2016; 1108: 209-222.

[27] Mohan J. Organic Spectroscopy:Principles and Applications. 2nd Ed. Harrow, UK: Alpha Science, 2004.

[28] Erdik E. Organik Kimyada Spektroskopik Yöntemler. 5. Bask1. Ankara, Türkiye: Gazi Kitabevi, 2008.

[29] Stuart BH. Infrared Spectroscopy: Fundamentals and Applications. 1st Ed. Chichester, England:Wiley 2004.

[30] Zhang XH, Zhan YH, Chen D, Wang F, Wang LY. Merocyanine dyes containing an isoxazolone nucleus: Synthesis, X-ray crystal structures, spectroscopic properties and DFT studies. Dyes and Pigm 2012; 93: 1408-1415.

[31] Jin RY, Sun X H, Liu YF, Long W, Chen B, Shen SQ, Ma HX. Synthesis, crystal structure, biological activity and theoretical calculations of novel isoxazole derivatives. Spectrochim Acta A 2016; 152: $226-232$. 
[32] Kalinowski HO, Berger S, Braun S. Carbon-13 NMR Spectroscopy. 1st ed. Chichester, UK John Wiley\&Sons, 1988.

[33] Pihlaja K, Kleinpeter E. Carbon-13 Chemical Shifts in Structural and Stereochemical Analysis. 1st ed. USA: Wiley-VCH Publishers, 1994.

[34] Balcı M. Nükleer Manyetik Rezonans Spektroskopisi. 2. Baskı. Ankara, Türkiye:ODTÜ Yayınc1lık, 2004.

[35] İnkaya E, Günnaz S, Özdemir N, Dayan O, Dinçer M, Çetinkaya B. Synthesis, spectroscopic characterization, X-ray structure and DFT studies on 2,6-bis(1-benzyl-1H-benzo[d]imidazol-2yl)pyridine. Spectr Acta Part A 2013; 103: 255-263.

[36] İnkaya E, Dinçer M, Ekici Ö, Çukurovalı A. N'-(2-methoxy-benzylidene)-N-[4-(3-methyl-3phenyl-cyclobutyl)-thiazol-2-yl]-chloro-acetic hydrazide: X-ray structure, spectroscopic characterization and DFT studies. J Mol Struct 2012; 1026:117-126.

[37] Fleming I. Frontier Orbitals and Organic Chemical Reactions. London, UK:Wiley, 1976.

[38] Tarı GÖ, Gümüş S, Ağar E. Crystal structure, spectroscopic studies and quantum mechanical calculations of 2-[((3-iodo-4-methyl)phenylimino)methyl]-5-nitro thiophene. Spectromica Acta Part A 2015; 141: 119-127.

[39] Vijayaraj R,Subramanian V, Chattaraj PK. Comparison of Global Reactivity Descriptors Calculated Using Various Density Functionals: A QSAR Perspective. J Chem Theory Comput 2009; 5(10): 2744-2753.

[40] Padmanabhan J, Parthasarathi R, Elango M, Subramanian V, Krishnamoorthy BS, GutierrezOliva S, Toro-Labbe A, Roy D R, Chattaraj PK. Multiphilic Descriptor for Chemical Reactivity and Selectivity. J. Phys. Chem. A 2007; 111: 9130-9138.

[41]a)Koopmans T. Physica 1. 1933; 104.

b)Vektariene A, Vektaris G. J Svoboda.A theoretical approach to the nucleophilic behavior of benzofused thieno[3,2-b]furans using DFT and HF based reactivity descriptors. ARKIVOC 2009; vii: 311-329.

[42] Mulliken RS. J Chem Phys 1934; 2: 782.

[43] a)Pearson RG.Hard and Soft Acids and Bases. J Am Chem Soc1963; 85:3533-3539

b)Pearson RG. Hard and soft acids and bases, HSAB, part 1: Fundamental principles. J Chem Educ1968;45(9): 581.

c)Pearson RG. Maximum Chemical and Physical Hardness. J Chem Educ1999;2 (76): 267.

[44] Pearson RG. Absolute electronegativity and hardness correlated with molecular orbital theory. Pro Nat Acad Scie 1986; 83: 8440-8441.

[45] Parr RG, Pearson RG. Absolute hardness: companion parameter to absolute electronegativity. J Am Chem Soc 1983;105: 7512-7516.

[46] Chattaraj PK, Sarkar U, Roy DR. Electrophilicity index. Chem Rev 2006; 106: 2065-2091.

[47] İnkaya E, Dinçer M, Ekici Ö, Çukurovalı A. 1-(3-Methyl-3-mesityl)-cyclobutyl-2-(5-pyridin-4-yl$2 \mathrm{H}-[1,2,4]$ triazol-3-ylsulfanyl)-ethanone: $\mathrm{X}$-ray structure, spectroscopic characterization and DFT studies. Spect Acta Part A 2013; 101: 218-227. 